\title{
SOSIALISASI DAN PENDAMPINGAN DALAM UPAYA PENINGKATAN EKSISTENSI OLAHRAGA PETANQUE DI KOTA YOGYAKARTA PADA MASA COVID-19
}

\author{
Widha Srianto, Yudi Karisma Sari \\ Universitas Tunas Pembangunan Surakarta, Indonesia \\ widha.srianto@lecture.utp.ac.id
}

\begin{abstract}
As the impact of Covid-19 outbreaks, several activities cannot be performed optimally, including activities of working, education, social, as well as sport. This also affects to activities of Fopi Kota Yogyakarta, therefore socialization and assistance activities are importantly required to be conducted for increasing the existence of petanque sport at Yogyakarta city. The activities' participants are from the management of Fopi Kota Yogyakarta involving lecturer, teacher, college students, and general public. The applied method is in the form of devotion activity including lecture, question and answer, and questionnaire to obtain the participants' responses. Data analysis is by giving 1 score for (Yes) answer and 0 for (No) answer, and then the results will be percentage. Based on the whole devotion activity, it can be concluded as follows: (1) The devotion activity can contribute positive impact to all elements of Fopi Kota Yogyakarta including the management, coach, as well as athlete, because it is valued as an innovation and able to broaden the knowledge about petanque sport. (2) Participants are motivated to perform positive activities during the Covid-19 outbreaks by conducting petanque sport. (3) This activity is possible to maintain the relationship of Yogyakarta city's petanque enthusiast during the Covid-19 outbreak by the online meeting.
\end{abstract}

Keywords: socialization, petanque, covid-19

\begin{abstract}
Abstrak
Masa pandemi covid-19 menjadikan semua kegiatan tidak bisa dilakukan dengan optimal, baik aktifitas kerja, aktifitas pendidikan, aktifitas social maupun aktifitas olahraga, hal ini berdampak pada kegiatan-kegiatan yang dilakukan oleh Fopi Kota Yogykarta, sehingga perlu upaya untuk tetap menjaga eksitensi dan tetap memberikan motivasi pecinta olahraga petanque dengan kegiatan-kegiatan positif, maka dengan ini perlu dilakukan kegiatan sosialisasi dan pendampingan dalam upaya peningkatan eksistensi olahraga petanque di Kota Yogyakarta, Peserta kegiatan dari unsur pengurus Fopi Kota Yogyakarta ini terdiri dari unsur dosen, guru, mahasiswa, dan masyarakat umum. Metode yang digunakan dalam pengabdian meliputi ceramah dan tanya jawab, dan diberikan kuesioner untuk mengetahui respon dari peserta, analisis data berupa skor 1 untuk jawaban (ya) dan 0 untuk jawaban (tidak) kemudian diprosentase. Berdasarkan rangkaian kegiatan pengabdian ini, maka dapat ditarik kesimpulan sebagai berikut: (1) Kegiatan pengabdian ini dapat memberikan dampak positif bagi semua unsur Fopi Kota Yogyakarta baik pengurus, pelatih, maupun atlet karena pengabdian ini dinilai sebagai sesuatu yang baru dan mampu menambah wawasan tentang olahraga petanque. (2) Peserta termotivasi untuk melakukan kegiatan positif dimasa pandemi covid-19 melalui olahraga petanque. (3) Kegiatan ini sarana dalam menjalin silaturahmi antar pecinta olahraga Petanque Kota Yogyakarta pada masa covid-19 dengan meeting online.
\end{abstract}

Kata Kunci: sosialisasi, petanque, covid-19

Submitted: 2020-06-20

Revised: 2020-07-15

Accepted: 2020-07-17 


\section{Pendahuluan}

Daerah Istimewa Yogyakarta memiliki potensi untuk penyumbang atlet maupun pelatih olahraga petanque, sehingga perlu dilaksanakan pengenalan olahraga petanque di kabupaten-kabupaten yang ada di Yogyakarta. Wilayah di Kota Yogyakarta memiliki potensi untuk mengembangkan olahraga petanque karena di wilayah Kota Yogyakarta sebagai pusat aktifitas, baik pendidikan, ataupun kegiatan yang lainnya.

Masa pandemi covid-19 menjadikan semua kegiatan tidak bisa dilakukan dengan optimal, baik aktifitas kerja, aktifitas pendidikan, aktifitas social maupun aktifitas olahraga. hal ini berdampak pada kegiatan-kegiatan yang dilakukan oleh Fopi Kota Yogykarta, sehingga perlu upaya untuk tetap menjaga eksitensi dan tetap memberikan motivasi pecinta olahraga petanque dengan kegiatan-kegiatan positif. maka dengan ini perlu dilakukan kegiatan sosialisasi dan pendampingan dalam upaya peningkatan eksistensi olahraga Petanque di Kota Yogyakarta.

Kegiatan ini sebagai komitmen Fopi Kota Yogyakarta dalam rangka mengenalkan olahraga petanque di wilayah Kota Yogyakarta Provinsi Daerah Istimewa Yogyakarta, sehingga diharapkan akan muncul baik pelatih, atlet, maupun pengurus yang berkompetensi baik demi memajukan olahraga petanque di Yogyakarta. Kegiatan ini perlu dilakukan berdasarkan identifikasi sebuah permasalahan antara lain:

1. Selama pamdemi covid-19 kepengurusan dan kegiatan olahraga petanque pasif.

2. Olahraga petanque harus menjadi motivasi dan dapat memberikan dampak psikis yang baik dari semua usur organisasi.

3. Berdasarkan diskusi WAG Grup Fopi Kota Yogyakarata, harus memiliki kegiatan positif dalam masa covid-19.

Pencapaian sasaran kegiatan perlu didukung oleh banyak pihak demi kelancaran kegiatan. Keberhasilan dari kegiatan ini perlu adanya koordinasi yang baik dari pelaksana kegiatan, pengurus dan pemateri. Kegiatan pengabdian masyarakat ini dibagi menjadi beberapa tahap yakni meliputi: 1) Tahap persiapan yang meliputi analisis permasalahan dan pemilihan materi, yaitu bagaimana permsalahan yang sedang timbul dalam kepengurusan selama masa covid-19 dan bentuk materi apa saja yang harus diberikan untuk tetap memberikan semangat dan meningkatkan eksistensi Fopi Kota Yogyakarta, 2) pemberian materi terbatas bagi pengurus, antara lain visi moisi kepengurusan Fopi Kota Yogyakarta, dampak covid-19 bagi Fopi Kota Yogyakarta, perkembangan dan peluang olahraga petanque bagi prestasi Indonesia. 3) diskusi melalui meeting online, yaitu pemberian referensi bagi pelatih dan atlet Fopi Kota yogyakarta serta peningkatan motivasi agar tetap menjalankan olahraga atau kegiatan positif pada masa covid-19, untuk mengurangi gangguan psikis dan kesehatan bagi pelatih dan atlet.

Pengabdian masyarakat ini memiliki target luaran, dimana terget luarannya adalah sebagai berikut:

1. Meningkatkan pengetahuan tentang nilai-nilai olahraga bagi masyarakat pelaku olahraga petanque

2. Memberikan referensi program latihan bagi atlet dan pelatih

3. Menjadikan kegiatan yang dilakukan sebagai nilai positif pada masa covid-19.

4. Membentuk hubungan baik antara pengurus Fopi Kota Yogyakarta dan lembaga Universitas Tunas Pembanguna (UTP) Surakarta sebagai bentuk pengabdian kepada masyarakat dalam rangka Tri Darma Perguruan Tinggi. 
5. Laporan kegiatan pengabdian masyarakat yang dipublikasikan.

\section{Metode}

Kegiatan pengabdian masyarakat ini melalui observasi awal pada tanggal 11 April 2020,. kegiatan ini terbagi menjadi 3 tahapan yaitu: perencanaan, pelaksanaan dan evaluasi. Tahap perencanaan adalah tahap perumusan masalah dan pencarian metode yang dilakukan untuk pemecahan masalah, tahapan ini merumuskan bentuk kegiatan serta langkah-langkah yang dilakukan dalam pengabdian masyarakat. Tahapan kedua adalah tahapan pelaksanaan, yaitu implementasi dari perumusan sebelumnya untuk dilaksanakan menjadi kegiatan dengan baik sesuai yang telah direncanakan, tahapan yang ketiga adalah tahapan evaluasi, yaitu tahapan yang untuk meninjau sejauh mana kegiatan tersebut bermanfaat dan terlaksana dengan baik. Kegiatan dilakukan dengan metode diskusi dan tanya jawab, selanjutnya peserta diberikan kuesioner melalui WA terkait evaluasi penilain hasil kegiatan.

\section{Hasil dan Pembahasan}

1. Pra kegiatan

Kegiatan perijinan bertujuan untuk memberitahukan surat ijin berupa undangan whatsapp kepada Ketua Umum Fopi Kota Yogyakarata dengan adanya kegiatan yang akan dilaksanakan, dan melakukan koordinasi melalui video call dengan pengurus terkait event kegiatan yang akan dilaksanakan, termasuk materi yang akan diberikan.

2. Pelaksanaan

Kegiatan dilaksanakan menggunakan metode diskusi dengan virtual (meeting online) dalam 2 hari yang berbeda yaitu kegiatan pertama terbatas dan yang kedua diskusi umum.

a. Diskusi terbatas bagi pengurus Fopi Kota Yogyakarta: kegiatan dilaksanakan pada tanggal 26 Mei tahun 2020 dibatasi hanya 15 orang pengurus inti dan pemateri. Kegiatan ini dilaksankan pada tanggal 29 Mei tahun 2020 dengan menggunakan aplikasi zoom berbayar sehingga kegiatan bisa dilakukan sampai selesai, kegiatan ini dilaksanakan dengan cara diskusi online. Kegiatan dimulai pada pukul 09.00 WIB sampai pukul 12.00 WIB. Kegiatan dibuka oleh Ketua Umum Fopi Kota Yogyakarta dan dilanjutkan dengan pemaparan materi oleh pemateri. Pemateri utama dalam kegiatan ini adalah Widha Srianto, S.Pd., Kor., M.Or sebagai akademisi dan sekaligus praktisi cabang olahraga petanque, penyampaian materi ini terkait dengan sejarah dan cara bermain petanque, bagaimanakah seorang pemula dapat bermain petanque dengan menyenangkan sekaligus dapat berprestasi baik ditingkat Daerah, Nasional, maupun Internasional, dan sekaligus menjelasakan teknik-teknik nermain petanque dengan benar serta cara mensosialisasikan. Kemudian materi selanjutnya adalah terakit dengan kontribusi dan peluang cabang olahraga sebagai olahraga prestasi, pemateri memaparkan terkait olahraga petanque memiliki kesempatan dan peluang yang sama dengan cabang olahraga yang lain. Selanjunya sesi yang terakhir adalah penyampain materi terkait dengan kontribusi olahraga petanque untuk memberikan dampak 
positif pada masa covid-19, materi ini disampaikan oleh Ketua Umum Fopi Kota Yogyakarta. Dengan adanya wabah covid-19 atau yang sering disebut corona tentunya semua orang kurang termotivasi dalam segala aktifitas, dan berdampak tidak baik pada psikis olahragawan. Sehingga pengurus Fopi Kota Yogyakarta memberikan arahan yang kepada atlet maupun pelatih bahwa olahraga petanque dapat sebagai alternatif kegiatan yang bisa dilakukan di rumah untuk mengisi waktu luang untuk tetap hidup sehat dan memberikan nilai positif pada saat masa covid-19.

b. Diskusi umum, kegiatan ini dilaksankan pada tanggal 29 Mei tahun 2020 dengan menggunakan aplikasi zoom berbayar sehingga kegiatan bisa dilakukan sampai selesai, kegiatan ini dilaksanakan dengan cara diskusi online yang dihadiri peserta kurang lebih 30 orang dari berbagai unsur kepengurusan Fopi Kota Yogyakarta, kegiatan ini dilaksanakan pukul 10.00 WIB sampai dengan pukul 12.00 dibuka oleh MC dan dilakukan pembukaan selanjutnya dengan pemaparan program latihan dan referensi terkait latihan petanque oleh Bapak Widha Srianto, dan Ibu Yudi Karisma Sari, S.Si., M.Or setelah dilakukan pemaparan oleh pemateri kemudian dilanjutkan tanya jawab terkait program latihan dan model latihan.

3. Pasca Kegiatan

Setelah pelaksanaan kegiatan kemudian dilakukan analisis untuk mengetahui sejauhmana kegiatan yang terlaksana dengan baik dan dapat memberikan wawasan yang bagi peserta kegiatan Pengabdian Masayarakat pada cabang olahraga petanque di Fopi Kota Yogyakarta. Peserta diberikan kuesioner melalui whatsapp dengan jawaban ya (1) dan tidak (0).

Tabel 1. Kuesinoer Peserta

\begin{tabular}{lll}
\hline \multicolumn{1}{c}{ Judul } & \multicolumn{1}{c}{ Pertanyaan } & No \\
\hline Sosialisasi dan pendampingan & Kemanfaatan Kegiatan / dampak & 1 \\
dalam upaya peningkatan & positif & 2 \\
eksistensi olahraga petanque & Motivasi & 3 \\
di Kota Yogyakarta pada masa & Hubungan social & \\
covid-19 & & \\
\hline
\end{tabular}

Hasil Kuesioner pengabdian masyarakat bagi peserta tentang dampak positif kegiatan adalah sebagai berikut:

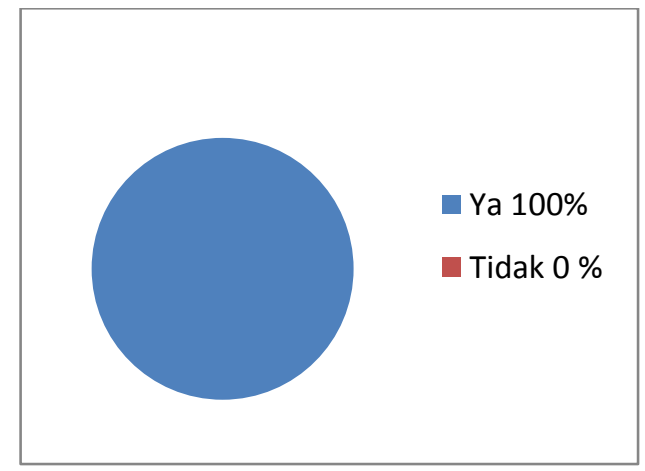

Gambar 1. Berdampak Positif 
Hasil Kuesioner pengabdian masyarakat bagi peserta tentang motivasi (mengurangi kebosanan) adalah sebagai berikut:

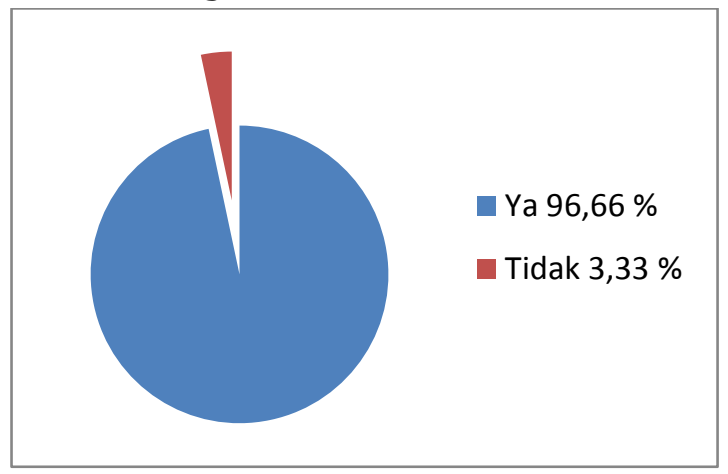

Gambar 2. Motivasi

Hasil Kuesioner pengabdian masyarakat peserta tentang hubungan sosial adalah sebagai berikut:

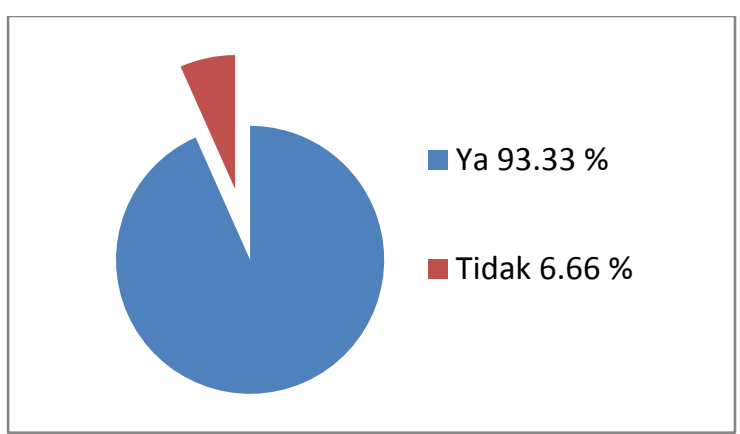

Gambar 3. Hubungan Sosial

4. Penyusunan laporan

Penyusunan laporan disusun setelah kegitan ini berakhir untuk melaporkan rangkaian dan hasil dari program kegiatan pengabdian masyarakat dan selanjutnya diterbitkan dalam jurnal pengabdian masyarakat.

\section{Kesimpulan}

Dalam pengabdian masyarakat yang berjudul sosialisasi dan pendampingan dalam upaya peningkatan eksistensi olahraga petanque di kota yogyakarta pada masa covid-19 menghasilkan kesimpulan sebagai berikut:

1. Kegiatan pengabdian ini dapat memberikan dampak positif bagi semua unsur Fopi Kota Yogyakarta baik pengurus, pelatih, maupun atlet karena pengabdian ini dinilai sebagai sesuatu yang baru dan mampu menambah wawasan tentang olahraga petanque.

2. Olahraga petanque sebagai solusi untuk memotivasi dan mengurangi kebosanan pada masa pandemic covid-19

3. Kegiatan ini sarana dalam menjalin silaturahmi antar pecinta olahraga Petanque Kota Yogyakarta pada masa covid-19 dengan meeting online. 


\section{Daftar Pustaka}

Ali Maksum. (2008). Metode Penelitian Olahraga. Surabaya: Unessa Press.

Kementerian Kesehatan Republik Indonesia. (2020). Pedoman Pencegahan dan Pengendalian Coronavirus Disease (Covid-19). Jakarta: Dirjen Pencegahan dan Pengendalian Penyakit.

Pengurus Besar Federasi Olahraga Petanque Indonesia. (2012). Program dan Teknik Dasar Bermain Petanque. Jakarta: PB FOPI

RSPI Sulianti Saroso. (2020). Persiapan Kewaspadaan di Rumah Tangga dan Sarana Pelayanan Kesehatan untuk Tangkal Penyakit corona virus (covid-19). Jakarta

Ramdan Pelana, Achmad Sofyan Hanif, Caca Isa Saleh. (2020). Teknik Dasar Bermain Olahraga Petanque. Jakarta: Rajawali Pers. 